\title{
Digestion of proteins of varying degradability in sheep. 3. Apparent and true digestibility in the small intestine and ileal endogenous flow of $\mathrm{N}$ and amino acids
}

\author{
J. van Bruchem, L. J. G. M. Bongers, J. D. van Walsem, W. Onck and \\ P. W. M. van Adrichem
}

Department of Animal Physiology, Agricultural University, Haarweg 10, 6709 PJ Wageningen, Netherlands

Received 7 August 1984; accepted 24 April 1985

Key-words: amino acid profile, endogenous protein

\section{Summary}

Mixed concentrates of which the protein degradability varied were fed to sheep provided with an infusion tube into the abomasum and with cannulas in the cranial duodenum and terminal ileum. Apparent digestibility in the small intestine of amino acid $\mathrm{N}$ varied from 57.0 to $73.2 \%$ and increased with increasing quantities of protein entering the small intestine. The mean true digestibility in the small intestine was $90.3 \%$. The apparent and true digestibilities of the individual amino acids varied considerably. Their mutual relationship is described. The protein leaving the small intestine consisted for $75 \%$ of endogenous protein $\left(321 \mathrm{mg} \mathrm{NAN} \mathrm{kg}{ }^{-3 / 4}\right.$ $\left.\operatorname{day}^{-1}\right)$.

\section{Introduction}

In ruminants, the ingested protein is extensively degraded by the rumen microbes. Thus protein entering the small intestine consists for the major part of microbial protein. Also undegraded dietary protein and endogenous protein contribute to intestinal protein supply, the proportion of dietary protein increasing with decreasing protein degradability. The contribution of protozoa to the biomass which becomes available for digestion in the small intestine is to be considered as well. Although literature data on this subject are quite variable, the general idea is that the quantity of protozoal proteins entering the small intestine may not be overlooked. Proportions of protozoal $\mathrm{N}$ amounting to $20-40 \%$ of microbial $\mathrm{N}$ entering the small intestine have been reported (Brandt \& Rohr, 1981; Tamminga, 1983).

The nutritive value of dietary $\mathrm{N}$ for ruminants is determined by the quantity of amino acids absorbed from the small intestine. Of common ruminant feedstuffs the dietary protein escaping rumen fermentation is often assumed to be well digestible 
in the small intestine, provided that they are not excessively protected by chemical or heat treatment. Digestibility may be increased by rumen incubation (Robinson $\&$ Tamminga, 1984). The proportion of dietary protein entering the small intestine under the present experimental conditions is given by van Bruchem et al. (1985b). Some recent papers are available on the digestibility of microbial $\mathrm{N}$ in the small intestine (Tas et al., 1981; Storm et al., 1983). In ruminants, the abomasal acid conditions are extended throughout the upper part of the small intestine. Nevertheless an excessive protein digestion capacity seems to be available. Hence the extent of protein digestion is mainly determined by protein digestibility, the major part of this process being completed in the cranial half of the small intestine (Ben Ghedalia et al., 1974; van Bruchem et al., 1983).

Protein leaving the ileum contains a considerable quantity of endogenous protein. This is probably not a result of its lower succeptibility to digestion but of the restricted time interval the endogenous proteins originating from the caudal part of the small intestine are subjected to proteolysis (van Bruchem et al., 1984). The present paper describes the apparent and true digestibility of $\mathrm{N}$ and amino acids in the small intestine. The quantity and composition of the ileal endogenous protein fraction were determined by regression analysis. It is also shown how apparent and true digestibility are mutually related.

\section{Materials and methods}

The experiments were conducted with two Texel wethers fitted with an infusion tube into the abomasum and cannulas into the cranial duodenum and terminal ileum.

With groundnut expeller (GE), potato protein (PP), dried breweries grains (BG) and peas (PE) as the main protein sources concentrate mixtures were composed of which the rumen protein degradability varied. GE and PP were fed at a higher (2) and lower (1) protein level, BG and PE only at the lower (1) level. The composition of the concentrates and the experimental design were as given by van Bruchem et al. (1985a). The experiments were conducted, samples analysed and data statistically handled as described in detail by van Bruchem et al. (1985b).

Student $T$ values for testing significances can be calculated dividing contrasts between rations by $\mathrm{SEM} \times \sqrt{2}(\mathrm{df}=29)$.

\section{Results}

The quantity of amino acids and $\mathrm{N}$ ingested and entering the small intestine as related to the amount and nature of the dietary protein source under the present experimental conditions were as reported by van Bruchem et al. (1985b). The same parameters in ileum and faeces are given in Tables 1 and 2, respectively. In Table 3 per individual ration the apparent digestibility of $\mathrm{N}$ and the individual amino acids is presented. The apparent digestibilities were quite low, probably caused by the ileal endogenous protein fraction being relatively important at the applied levels of daily $\mathrm{N}$ intake of $0.76-1.60 \mathrm{~g} \mathrm{~N} / \mathrm{kg}^{3 / 4}$. The true digestibility of $\mathrm{N}$ and the individual amino 
DIGESTION OF PROTEINS OF VARYING DEGRADABILITY IN SHEEP. 3

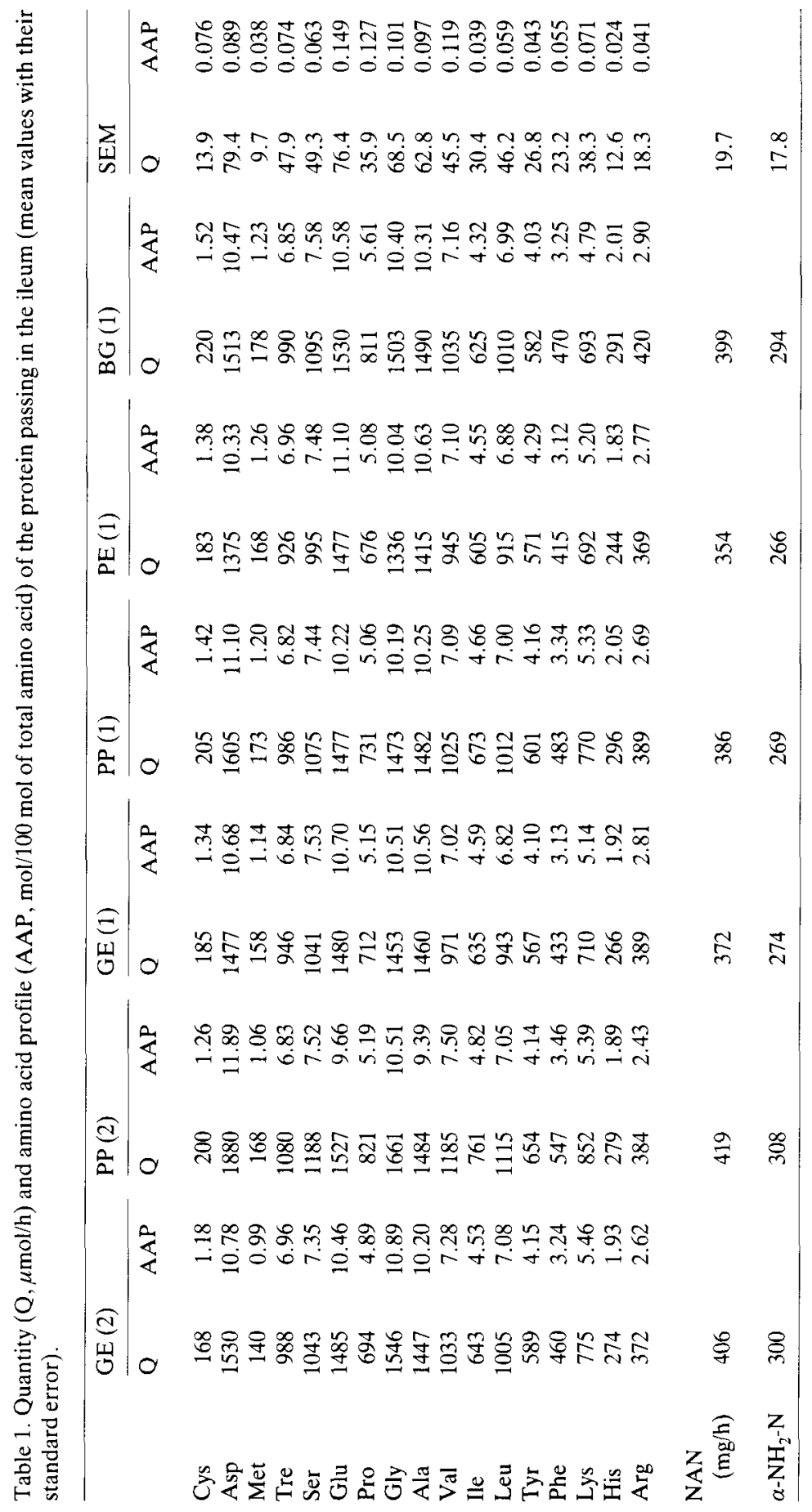

Neth. J. agric. Sci. 33 (1985) 


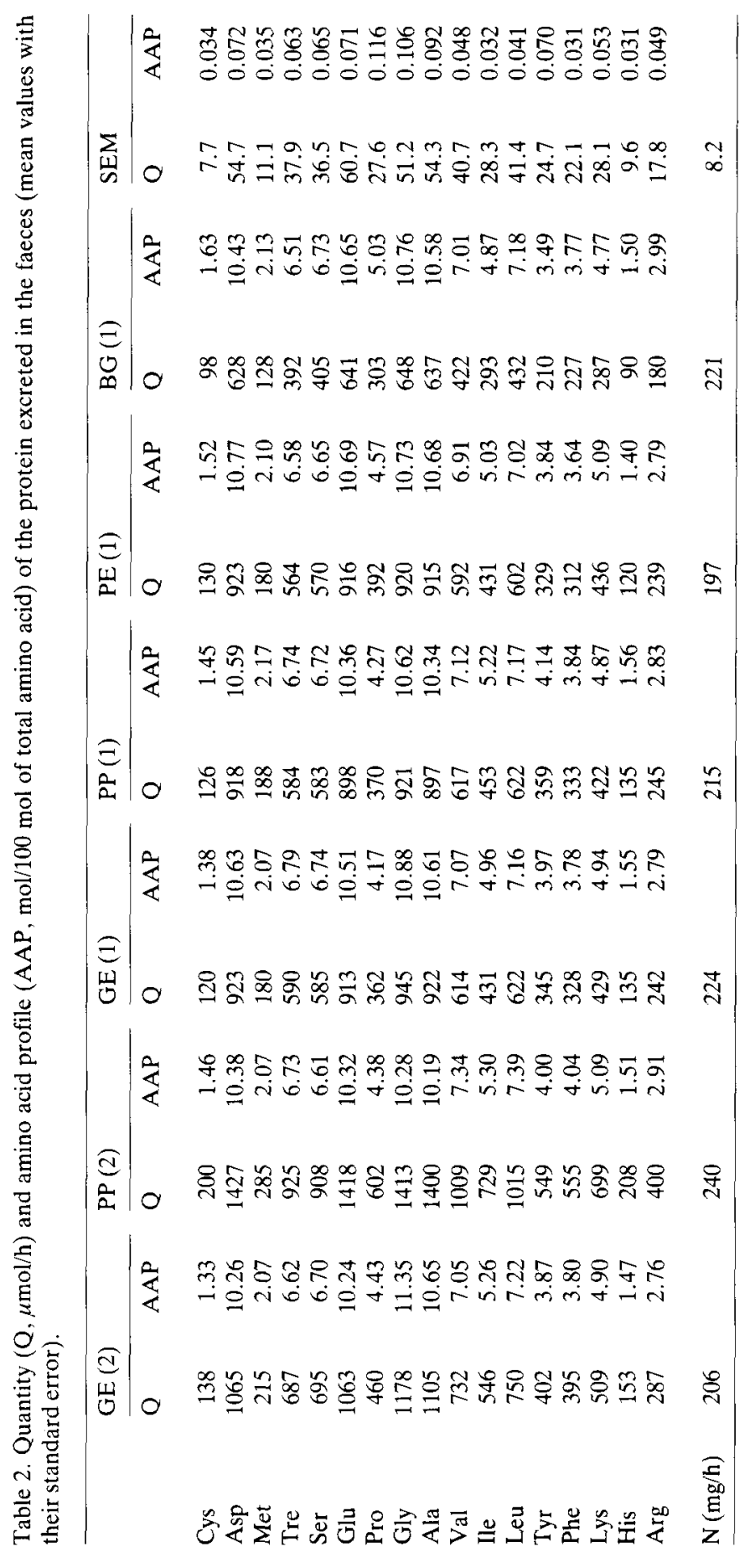




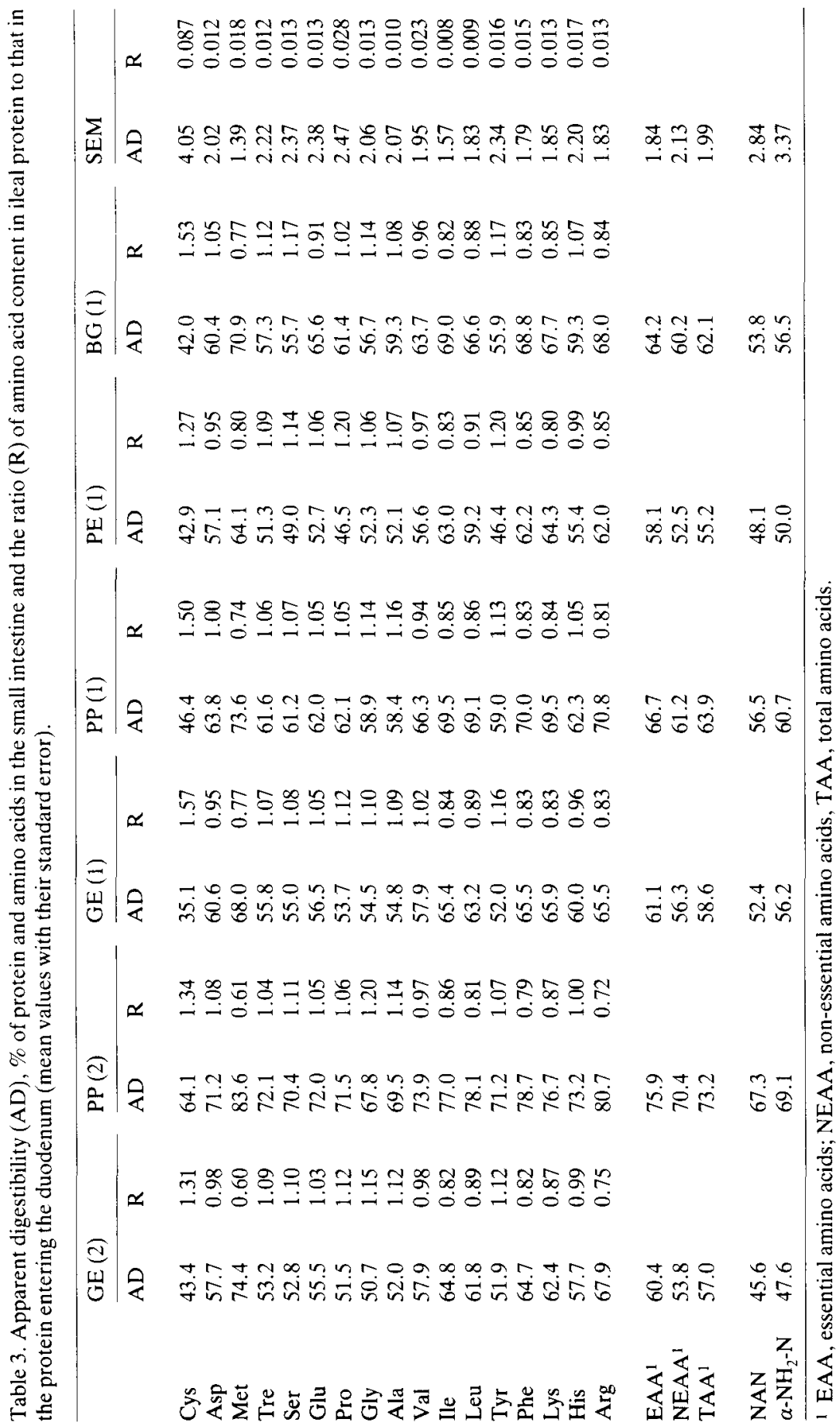

Neth. J. agric. Sci. 33 (1985) 
acids was determined by linear regression, relating the amounts passing at the terminal ileum (Y) to those at the cranial duodenum (X). The true digestibility in the small intestine (1-b) and the ileal endogenous loss $(a)$ of $\mathrm{N}$ and the individual amino acids were estimated according to the model:

$$
\mathrm{Y}=a+b \mathrm{X}
$$

For this approach, variability of duodenal and ileal passage rates of $\mathrm{N}$ and amino acids is a prerequisite. For this purpose all intestinal passage rates after feeding the different rations were used. Since even with less easily degradable proteins still the major part of the protein entering the small intestine is of microbial origin, the figures obtained refer predominantly to microbial protein. Of these pooled data the apparent and true digestibilities are given in Table 4. In this table the amount and composition of the ileal endogenous protein is presented as well. It appeared that the protein (TAA) passing in the terminal ileum consisted on average for $73.4 \%$ of protein of endogenous origin. For NAN and $\alpha-\mathrm{NH}_{2}-\mathrm{N}$ these values were 74.0 and $77.9 \%$, respectively. In consequence, the amino acid profile (AAP) of ileal protein relative to that of the protein entering the small intestine is determined for $26.6 \%$ by the AAP of the undigested residue of the duodenal protein and for $73.4 \%$ by the

Table 4. Mean true (TD) and apparent digestibility (AD) (\%) in the small intestine and ileal endogenous flow (IEF) of amino acids, $\mathrm{NAN}$ and $\alpha-\mathrm{NH}_{2}-\mathrm{N}$, with $\mathrm{SE}$ in parentheses.

\begin{tabular}{lllr}
\hline & TD & AD & IEF $(\mu \mathrm{mol} / \mathrm{h})$ \\
Cys & $85.3(5.18)$ & $45.7(2.14)$ & $139(20.2)$ \\
Asp & $83.9(2.19)$ & $61.8(1.10)$ & $881(96.8)$ \\
Met & $94.7(1.89)$ & $72.4(1.15)$ & $131(12.8)$ \\
Tre & $91.5(2.22)$ & $58.6(1.44)$ & $773(58.4)$ \\
Ser & $90.0(2.38)$ & $57.4(1.46)$ & $808(65.5)$ \\
Glu & $93.5(3.14)$ & $60.7(1.42)$ & $1238(128.0)$ \\
Pro & $90.2(1.81)$ & $57.8(1.70)$ & $554(36.3)$ \\
Gly & $85.6(2.84)$ & $56.8(1.22)$ & $979(104.9)$ \\
Ala & $91.7(2.85)$ & $57.7(1.29)$ & $1164(104.9)$ \\
Val & $89.7(1.81)$ & $62.7(1.26)$ & $732(55.5)$ \\
Ile & $89.9(1.62)$ & $68.1(0.98)$ & $439(36.6)$ \\
Leu & $92.7(1.60)$ & $66.3(1.25)$ & $768(53.8)$ \\
Tyr & $92.0(2.10)$ & $56.1(1.59)$ & $479(31.6)$ \\
Phe & $91.1(1.52)$ & $68.3(1.12)$ & $328(25.3)$ \\
Lys & $90.1(2.08)$ & $67.8(1.05)$ & $508(52.2)$ \\
His & $89.2(2.56)$ & $61.3(1.27)$ & $197(20.0)$ \\
Arg & $96.9(2.06)$ & $69.2(1.20)$ & $345(28.5)$ \\
& & & \\
EAA & & & \\
NEAA & $91.5(1.78)$ & $64.4(1.21)$ & $4865(359.6)$ \\
TAA & $88.8(2.46)$ & $59.0(1.29)$ & $5608(507.5)$ \\
& $90.3(2.10)$ & $61.7(1.25)$ & $10530(856.5)$ \\
NAN & $88.5(3.27)$ & $54.0(1.59)$ & $288(29.9)^{2}$ \\
$\alpha$-NH ${ }_{2}-\mathrm{N}$ & $90.8(3.72)$ & $56.7(1.76)$ & $222(26.5)^{2}$ \\
\hline
\end{tabular}

1 EAA, essential amino acids; NEAA, non-essential amino acids; TAA, total amino acids.

2 In $\mathrm{mg} / \mathrm{h}$. 
Table 5. The overall ratio's of amino acid contents in the duodenal protein residue passing in the ileum (R1), in ileal endogenous protein (R2) and in ileal total protein (R3) relative to the amino acid contents in duodenal protein.

\begin{tabular}{llll}
\hline & R1 & R2 & R3 \\
Cys & 1.48 & 1.39 & 1.41 \\
Asp & 1.63 & 0.78 & 1.01 \\
Met & 0.54 & 0.77 & 0.70 \\
Tre & 0.86 & 1.15 & 1.07 \\
Ser & 1.01 & 1.15 & 1.11 \\
Glu & 0.66 & 1.17 & 1.03 \\
Pro & 0.99 & 1.10 & 1.07 \\
Gly & 1.46 & 1.02 & 1.14 \\
Ala & 0.84 & 1.22 & 1.12 \\
Val & 1.04 & 0.94 & 0.97 \\
Ile & 1.02 & 0.76 & 0.83 \\
Leu & 0.74 & 0.91 & 0.86 \\
Tyr & 0.81 & 1.25 & 1.13 \\
Phe & 0.90 & 0.78 & 0.81 \\
Lys & 1.00 & 0.79 & 0.84 \\
His & 1.09 & 0.98 & 1.02 \\
Arg & 0.31 & 0.97 & 0.80 \\
\hline
\end{tabular}
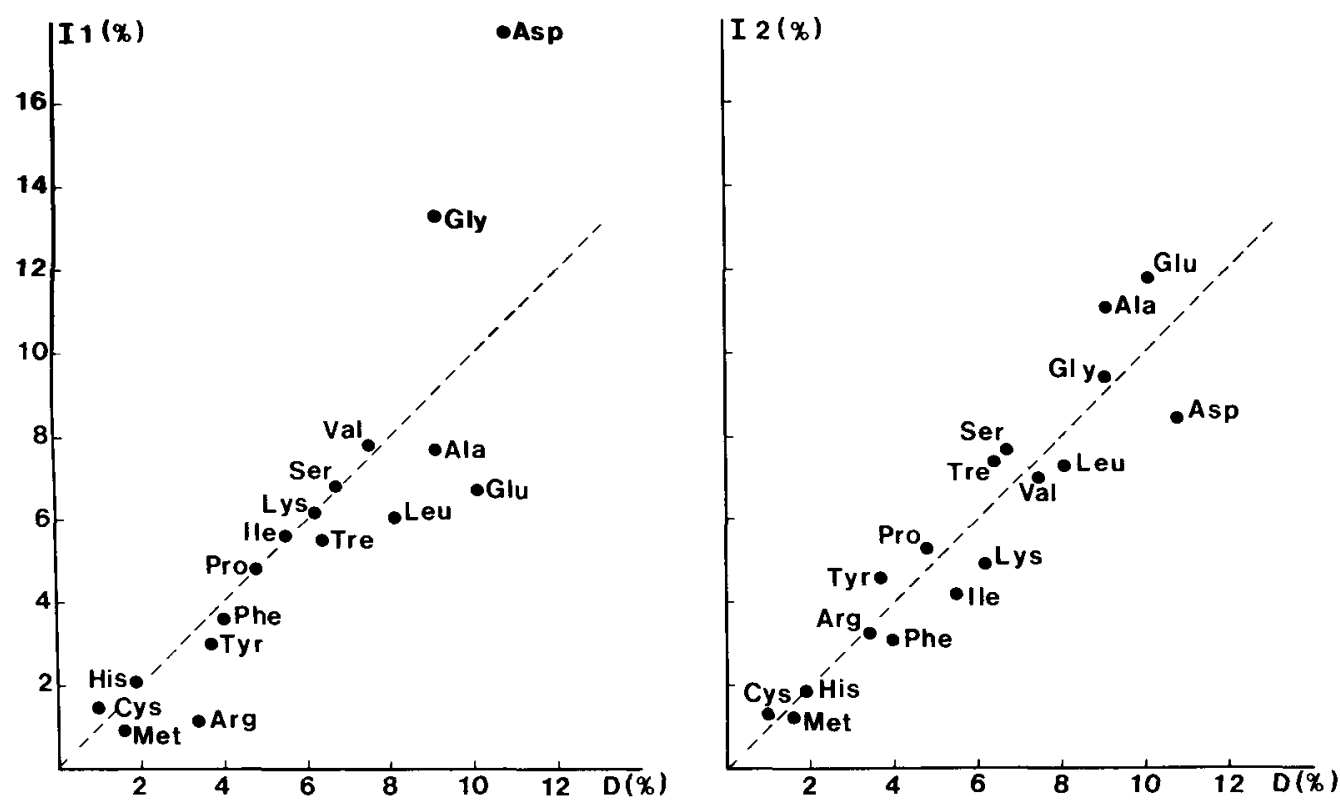

Fig. 1. The amino acid profiles ( $\mathrm{mol} / 100 \mathrm{~mol}$ of total amino acid) of the duodenal protein residue passing in the ileum (I1) and of ileal endogenous protein (I2) as related to that of the protein entering the small intestine (D). 

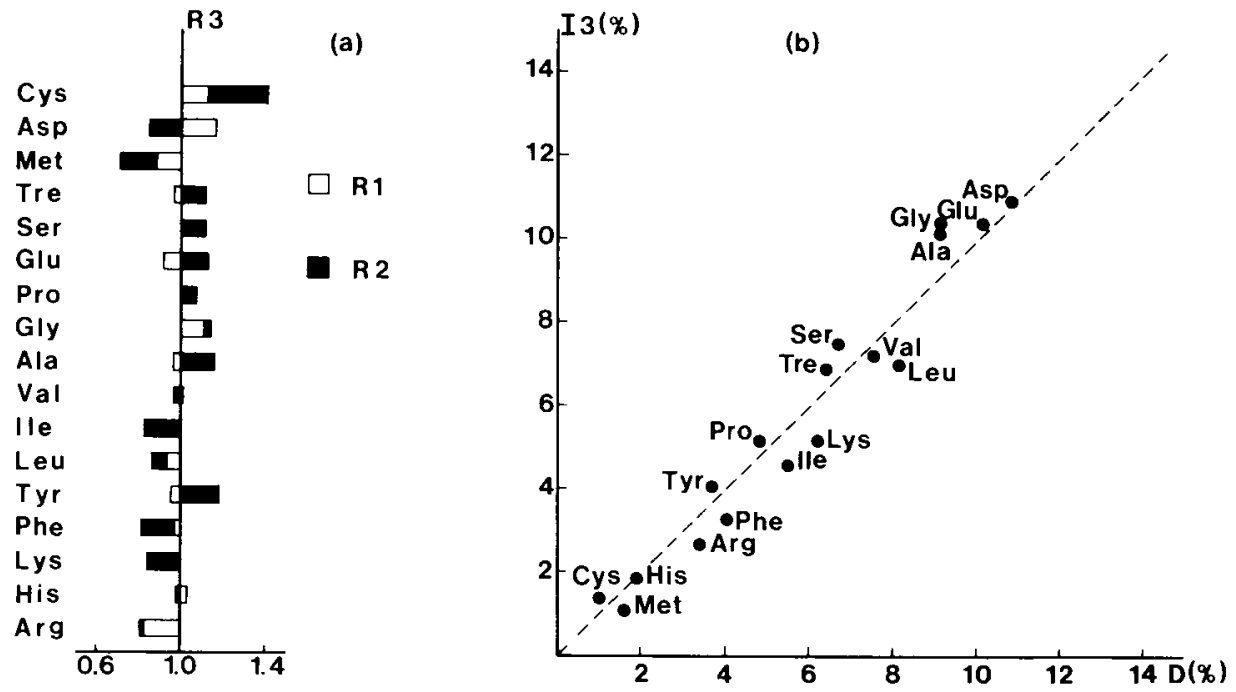

Fig. 2. (a) The ratios of the amino acid contents in the duodenal protein residue passing in the ileum (R1) and ileal endogenous protein (R2) as contributing to those in ileal total protein (R3) relative to the amino acid contents in duodenal protein. (b) The amino acid profile ( $\mathrm{mol} / 100 \mathrm{~mol}$ of total amino acid) of ileal protein (I3) as related to that of the protein entering the small intestine (D).

AAP of the ileal endogenous protein. The AAPs of both ileal protein fractions and of ileal total protein, relative to the AAP of duodenal protein, are presented in Table 5. In this table, $\mathrm{R} 3$ represents the relative AAP of ileal total protein. $\mathrm{R} 3$ can also be derived from R1 and R2 as $0.266 \mathrm{R} 1+0.734 \mathrm{R} 2$.

The AAPs of the ileal protein fractions relative to that of duodenal protein are presented graphically in Fig. 1. In these plots amino acids with $\mathrm{R}$ values below unity are located below the line of identity. Of amino acids with $R$ values exceeding unity the opposite is the case.

Of each individual amino acid the apparent digestibility is determined by its true digestibility and by its content in ileal endogenous protein. This is graphically presented in the histogram of Fig. 2, showing for example that the lower apparent digestibility of cysteine $(\mathrm{R} 3=1.41)$ is caused by a lower true digestibility $(\mathrm{R} 1=1.48)$ and a relatively high content in ileal endogenous protein $(\mathrm{R} 2=1.39)$. The moderate apparent digestibility of aspartic acid $(\mathrm{R} 3=1.01)$ is a result of a lower true digestibility compensated by the relatively low content in endogenous protein. Finally, for example, the relatively high apparent digestibility of isoleucine appears to result from a low content in endogenous protein, whereas that of arginine is a result of an extremely high true digestibility.

\section{Discussion}

Both in sheep and cows, apparent digestibilities (AD) of the individual amino acids in general slightly higher than $70 \%$ have been reported. The present experiments 
gave in general lower digestibilities, especially with lower quantities of protein entering the small intestine. With an increasing amount of protein reaching the duodenum, a situation more comparable to that in dairy cattle, a normal AD was obtained. This indicates that the quantity of endogenous protein produced does not increase proportionally to the small intestinal protein flow. AD of amino acid $\mathrm{N}$ (TAA) showed to be higher than that of NAN, in line with the results of Coelho da Silva et al. (1972a, b). The present results indicate that $\alpha-\mathrm{NH}_{2}-\mathrm{N}$ according to van Slijke overestimate the quantity of amino acid $\mathrm{N}$ passing into the small intestine as can be deduced from the ileal data given in Table 1 and from the duodenal data as reported by van Bruchem et al. (1985b). AD of $\alpha-\mathrm{NH}_{2}-\mathrm{N}$ was higher than of NAN but lower than of TAA.

Proteins which were less easily degraded in the forestomachs (PP and BG) showed to be well digestible in the small intestine. This is in line with the results obtained with small nylon bags, incubated in the rumen of cows, and then introduced into the duodenum and collected from the faeces ( $\mathrm{S}$. Tamminga, personal communication).

Among amino acids, AD differed highly significantly, being lowest for cysteine and highest for methionine. In general, the order of the results obtained was quite in line with literature data on cattle and sheep (Coelho da Silva, 1972a, b; Armstrong \& Hutton, 1975; Tamminga, 1980). Among data available in literature some remarkable differences can be noticed. For example, Armstrong \& Hutton (1975) found the highest $\mathrm{AD}$ for cysteine, whereas this amino acid in general, including our results, is least apparently digestible. In comparison with the data of Coelho da Silva $(1972 \mathrm{a}, \mathrm{b})$, we obtained a relatively higher AD for phenylalanine but a lower one for tyrosine.

Whether the $\mathrm{AD}$ values obtained are determined by true digestibility (TD) or by the ileal endogenous loss of the individual amino acids could be determined by the linear regression method as was also applied by Tas et al. (1981) and Storm et al. (1983). The results presented in Table 4 en Fig. 2 present the interrelationship between $\mathrm{AD}$ and $\mathrm{TD}$, demonstrating that a relatively high $\mathrm{AD}$ does not necessarily coincide with a high TD. For example, of aspartate and glutamate the ADs are of the same order but the TDs differ considerably. Cysteine, however, shows a low $\mathrm{TD}$ as well, whereas on the other hand both the methionine and arginine highest AD values coincide with the highest TD values.

The present experiments showed a higher true digestibility of TAA in comparison with the data obtained by Storm et al. (1983) after intra-abomasal infusion of microbial protein. The order of our TD values, however, is quite comparable. Slight relative positive deviations were obtained for cysteine, proline and histidine and relatively negative ones for aspartate, glycine, phenylalanine and lysine.

The quantity of endogenous protein leaving the ileum found in the present experiments differed quite considerable from that reported by Storm et al. (1983). They reported an ileal endogenous loss of $\mathrm{N}$ of $37 \mathrm{mg} \mathrm{N} / \mathrm{kg}^{3 / 4}$. Based on a live weight of 60 $\mathrm{kg}$, we obtained a daily quantity of $321 \mathrm{mg} \mathrm{NAN} / \mathrm{kg}^{3 / 4}$, a value which agrees with that obtained by van Bruchem et al. (1985c) after infusion of non-microbial proteins into the abomasum. The extreme difference between our results and that of 
Storm et al. (1983) must be caused by the low quantity of dry matter passing in the small intestine in their infusion experiments. Schwarting \& Kaufmann (1978) calculated an ileal flow of endogenous protein of $26 \mathrm{~g}$ per $\mathrm{kg}$ dry matter intake. This figure was based on a TD of $85 \%$. With a TD of $90 \%$, this figure should have been $32.5 \mathrm{~g}$ delivering $241 \mathrm{mg} \mathrm{N} / \mathrm{kg}^{3 / 4}$ daily based on a live weight of the sheep of $60 \mathrm{~kg}$. This figure is slightly lower than ours, but certainly also considerably higher than that obtained by Storm et al. (1983). Our ileal endogenous protein fraction showed a different amino acid profile as well. On a molar basis ileal endogenous protein contained higher fractions of cysteine, proline and histidine but considerably lower fractions of glutamate, alanine, tyrosine and lysine. This indicates that possibly the different fractions contributing to endogenous protein are affected in different ways by the passage of dry matter.

In sheep, it has been established that the overall apparent protein digestibility is consistently higher than in cattle, both fed at maintenance level (Schiemann et al., 1971). The present experiments showed indeed a high protein digestive capacity in the small intestine. It is difficult to judge whether this difference is caused by a lower protein digestive capacity in the small intestine of cattle. This cannot be deduced from the figures on apparent digestibility given by Tamminga (1980), since these depend on the quantity of protein passing through the small intestine as well.

\section{Acknowledgements}

The authors gratefully acknowledge Messrs G. A. Bangma and G. van Gelderen for expert assistence during the experiments, the students Messrs H. J. Stormink and S. M. G. Rouwers for their substantial contribution and Prof. S. Tamminga and Dr W. A. G. Veen for advice and discussion during the course of this study.

\section{References}

Armstrong, D. G. \& K. Hutton, 1975. Fate of nitrogenous compounds entering the small intestine. In: I. W. McDonald \& A. C. I. Warner, Proceedings 4th International Symposium on Ruminant Physiology (Sydney, August 1974). The University of New England Publishing Unit, p. 432-447.

Ben-Ghedalia, D., H. Tagari \& A. Bondi, 1974. Protein digestion in the intestine of sheep. British Journal of Nutrition 31: 125-142.

Brandt, M. \& K. Rohr, 1981. Beiträge zur Quantifizierung der N-Umsetzungen in den Vormägen von Milchkühen. 1. Mitteilung. Bestimmung des Mikrobenstickstoffs im Duodenalchymus mit Hilfe von ${ }^{15}$ N. Zeitschrift für Tierphysiologie, Tierernährung und Futtermittelkunde 46: 39-48.

Bruchem, J. van, G. A. Bangma \& S. C. W. Lammers-Wienhoven, 1983. Digestion of non-microbial protein in the small intestine of sheep as related to the site and time interval of post-ruminal infusion. In: R. Pion, M. Arnal \& D. Bonin, Proceedings 4th EAAP Symposium on Proteins Metabolism and Nutrition (Clermont-Ferrand, 5-9 September 1983). EAAP Publication No 31, Vol. II: 313-316.

Bruchem, J. van, G. A. Bangma, W. Onck en P. W. M. van Adrichem, 1984. Produktie en herbenutting van endogeen eiwit in de dunne darm bij het schaap. Verslag 9de Studiedag Nederlandstalige Voedingsonderzoekers (Utrecht, 17 April 1984), p. 15-16.

Bruchem, J. van, S. M. G. Rouwers, G. A. Bangma, C. P. Leffering \& P. W. M. van Adrichem, 1985 a. Digestion of proteins of varying degradability in sheep. 1. Fermentation in and rate of passage from the reticulorumen. Netherlands Journal of Agricultural Science 33: 263-272. 
Bruchem, J. van, S. M. G. Rouwers, G. A. Bangma, S. C. W. Lammers-Wienhoven \& P. W. M. van Adrichem, 1985b. Digestion of proteins of varying degradability in sheep. 2. Amount and composition of the protein entering the small intestine. Netherlands Journal of Agricultural Science 33: 273284.

Bruchem, J. van, G. A. Bangma, S. C. W. Lammers-Wienhoven \& P. W. M. van Adrichem, 1985c. Digestion of non-microbial protein and amino acids in the small intestine of sheep as affected by peptic proteolysis in the abomasum. Zeitschrift für Tierphysiologie, Tierernährung und Futtermittelkunde 54: 113-121.

Coelho da Silva, J. F., R. C. Seeley, D. J. Thomson, D. E. Beever \& D. G. Armstrong, 1972a. The effect in sheep of physical form on the sites of digestion of a dried lucerne diet. 2. Sites of nitrogen digestion. British Journal of Nutrition 28: 43-61.

Coelho da Silva, J. F., R. C. Seeley, D. E. Beever, J. H. D. Prescott \& D. G. Armstrong, 1972b. The effect in sheep of physical form and stage of growth on the sites of digestion of a dried grass. 2. Sites of nitrogen digestion. British Journal of Nutrition 28: 357-371.

Robinson, P. H. \& S. Tamminga, 1984. Verteringsfysiologische studies met nylon zakjes in pens en darm. Verslag 9de Studiedag Nederlandstalige Voedingsonderzoekers (Utrecht, 17 April 1984), p. 11-12.

Schwarting, G. \& W. Kaufmann, 1978. Die Verdaulichkeit des Proteins beim Wiederkäuer. Zeitschrift für Tierphysiologie, Tierernährung und Futtermittelkunde 40: 6-18.

Storm, E., D. S. Brown \& E. R. Ørskov, 1983. The nutritive value of rumen micro-organisms in ruminants. 3. The digestion of microbial amino and nucleic acids in and losses of endogenous nitrogen from, the small intestine of sheep. British Journal of Nutrition 50: 479-485.

Schiemann, R., K. Nehring, L. Hoffmann, W. Jentsch \& A. Chudy, 1971. Energetische Futterbewertung und Energienormen. VEB Deutsche Landwirtschaftsverlag, Berlin.

Tamminga, S., 1980. Amino acid supply and utilisation in ruminants. In: H. J. Oslage \& K. Rohr, Proceedings 3rd EAAP Symposium on Protein Metabolism and Nutrition (Braunschweig, 5-9 May 1980). EAAP Publication No 27, Vol. II: 379-399.

Tamminga, S., 1983. Recent advances in our knowledge on protein digestion and absorption in ruminants. In: M. Arnal, R. Pion \& D. Bonin, Proceedings 4th EAAP Symposium on Protein Metabolism and Nutrition (Clermont-Ferrand, 5-9 September 1983). EAAP Publication No 31, Vol. I: 263-288.

Tas, M. V., R. A. Evans \& R. F. E. Axford, 1981. The digestibility of amino acids in the small intestine of sheep. British Journal of Nutrition 45: 167-174. 